Available online at GSC Online Press Directory

GSC Biological and Pharmaceutical Sciences

e-ISSN: 2581-3250, CODEN (USA): GBPSC2

Journal homepage: https://www.gsconlinepress.com/journals/gscbps

(RESEARCH ARTICLE)

\title{
Utilization of tea plantation weeds to produce vermicompost and estimation of physiochemical changes during its production
}

\author{
Mukherjee Mainak ${ }^{1}$, Sarkar Sahadeb ${ }^{2}$, Saha Sumedha ${ }^{2}$ and Bhattacharya Malay ${ }^{2, *}$ \\ ${ }^{1}$ Soil analysis Laboratory, Department of Tea Science, University of North Bengal, Siliguri, 734013, Darjeeling, India. \\ ${ }^{2}$ Molecular Biology and Tissue Culture Laboratory, Department of Tea Science, University of North Bengal, Siliguri, \\ 734013, Darjeeling, India.
}

Publication history: Received on 01 December 2018; revised on 28 December 2018; accepted on 29 December 2018

Article DOI: https://doi.org/10.30574/gscbps.2018.5.3.0153

\begin{abstract}
Application of inorganic fertilizers from the period of green revolution have increased food production by a number of times confirming the food security of the country but it has caused environmental degradation leading to health problems on animals and humans. It has forced the researchers to find out the alternative of inorganic agriculture that can balance the production and preserve the ecosystem. Vermicompost is one of them which can make a balance. Investigation was carried out to compost tea garden weeds by earthworms and assesses changes of some physiochemical properties during the process of vermicomposting. Samples for physiochemical assessment were drawn from each treatment at an interval of fifteen days. The maximum moisture content was recorded on $15^{\text {th }}$ day $(64.07 \%)$ and the minimum moisture content was recorded on $90^{\text {th }}$ day $(18.86)$. Rise in $\mathrm{pH}$ level was observed on $30^{\text {th }}$ day but thereafter declined gradually till $75^{\text {th }}$ day. There was a slight rise in $\mathrm{pH}$ level after $75^{\text {th }}$ day. The maximum percentage organic carbon in the vermicast was recorded to $32.87 \%$. The percentage of organic carbon varied within $21.77 \%$ to $32.87 \%$. The percentage of nitrogen varied from 1.53 to $1.78 \%$. The percentage of available phosphorus ranged between 0.15 to $0.44 \%$. The percentage of available potassium in from of potash ranged between 0.65 to $1.05 \%$. Vermicompost produced from tea plantation weeds to some extend may reduce the excessive use of chemical fertilizers in the plantations.
\end{abstract}

Keywords: Tea plantation; Weeds; Vermicompost; Physiochemical

\section{Introduction}

Green revolution in the 1960's has tremendously enhanced the agricultural production mainly due to the abundant use of fertilizers, pesticides, improved seed varieties, cultivars and other inputs. However the unilateral use of chemical fertilizers devoid of organic resources, have made our soil sick and problematic. Deterioration of soil health is the prime concern of modern agriculture. So, it is imperative to recycle organic matter in soil in order to regain soil health. The awareness of organic matter and concept of organic agriculture is gaining impetus among our farmers in recent years to produce good quality consumable agricultural produces. In this context, recycling of biological wastes of different sources is helpful and can reduce the environmental pollution.

Earthworms can be used to dispose-off all sorts of organic wastes [1]. The start of using earthworms in processing organic wastes was initiated during 1978. The main goal and benefit of using earthworms for waste management is to convert organic waste into fertilizers [2]. Worms convert 160000 tonnes of waste into fertilizer every year [3].

\footnotetext{
${ }^{*}$ Corresponding author

E-mail address: malaynbu@gmail.com
} 
Organic wastes of tea plantations like fallen leaves, weed clippings etc are rich source of nutrients. But, direct incorporation of these waste materials to the soil may cause wastage due to immobilization of nutrients in soil [4]. So, these organic wastes can be changed to organic fertilizers by utilizing earthworms. The process of vermicomposting involves several enzymes along with physiochemical and biological changes. Enzymes carry out different type of transformation during the composting process and are good indicators of the steps of composting process [5]. Urease is a hydrolase, involved in the nitrogen transformation in compost. However, phosphatases are also hydrolases concerned with the conversion of organic phosphorus to inorganic form [6-7]. The disappearance of resistant organic substances is however governed by the environmental changes during composting process [8-11]. So, there are several physiochemical changes that take place during the process of composting and the level of pH, organic carbon, Nitrogen, Phosphorus, potassium etc. goes on changing. Though, any organic source can be used as a substrate to produce vermicompost, but use of tea plantation weeds for producing vermicompost are lacking. Hence, an investigation has been carried out to evaluate the changes of some physio-chemical properties during the process of vermicomposting by using tea plantation weeds.

\section{Material and methods}

The experiment was conducted by growing earthworms on tea garden weeds supplemented with Cowdung (30\%). The ratio of weed biomass and Cowdung was at the ratio of 7:3. The weeds were collected from the tea plantations of University of North Bengal. A total number of ten earthen pots of equal size and shape (36 liter volume) were used for the present study. Around 200 earthworms were added to each earthen pot to initiate and carry on composting. The earthen pots for the experiment were maintained in shade condition to keep balance of humidity and temperature. Samples were drawn from each treatment at an interval of fifteen days starting from the fifteenth day till ninety days $\left(15^{\text {th }}, 30^{\text {th }}, 45^{\text {th }}, 60^{\text {th }}, 75^{\text {th }}\right.$ and $90^{\text {th }}$ day $)$ for downstream analysis.

\subsection{Preparation of samples for analysis}

The vermicompost collected from all ten earthen pots (20 grams each) were mixed thoroughly. They were left on plastic trays under shade conditions for complete drying. Debris from the samples like roots, pebbles etc. were removed by hand. The clean air-dried samples were passed through $2 \mathrm{~mm}$ sieve and pressed with mortar and pestle. The samples are further passed through a finer mesh sieve $(0.5 \mathrm{~mm})$ for determination of organic carbon and NPK. All the experiments were repeated thrice.

\subsection{Estimation of moisture and $\mathrm{pH}$ content}

For determination of moisture content of vermicompost, fresh weight $\left(\mathrm{W}_{\mathrm{f}}\right)$ were measured and recorded. The vermicompost were transferred to porcelain crucible and hot air oven dried at $105^{\circ} \mathrm{C}$ for 48 hours. The dried sample $\left(\mathrm{W}_{\mathrm{d}}\right)$ were measured. The moisture percentage were calculated by the formula

$$
\text { Moisture content }(\%)=\frac{W_{f}-W_{d}}{W_{f}} \times 100
$$

For estimation of $\mathrm{pH}, 20 \mathrm{~g}$ of air dried sample was added to $50 \mathrm{ml}$ of neutral water in a conical flask and mixed thoroughly by shaking over a mechanical shaker for minimum 30 minutes. The contents of the conical flask were transferred to a $100 \mathrm{ml}$ beaker. Finally, previously calibrated electrode of a soil ph meter was dipped into the beaker to measure the pH. Three replicates were tested for each sample and their $\mathrm{pH}$ was calculated.

\subsection{Determination of organic carbon content}

Quantification of organic carbon was determined by Chromic acid method [12] with minor modification. $0.1 \mathrm{~g}$ of air dried and sieved samples was taken in a conical flask. $10 \mathrm{ml}$ of $1 \mathrm{~N}$ Potassium dichromate $\left(\mathrm{K}_{2} \mathrm{Cr}_{2} \mathrm{O}_{7}\right)$ solution was added and shake vigorously to mix. Then $20 \mathrm{ml}$ of conc. $\mathrm{H}_{2} \mathrm{SO}_{4}$ was added and the flask was swirled for 2 minutes. The flask was allowed to stand for 30 minutes for completing the reaction. $170 \mathrm{ml}$ of water was poured to the flask to dilute the suspension. After adding $0.2 \mathrm{~g}$ of Sodium fluoride $(\mathrm{NaF})$ and $1 \mathrm{ml}$ of diphenylamine indicator, back titration was conducted with $0.5 \mathrm{~N}$ ferrous ammonium sulphate, till the colour changed from violet through blue to bright green. The volume of the ferrous ammonium sulphate was noted. One blank (without sample) titration was done in a similar manner. Percentage of organic Carbon in the vermicompost was calculated by following equation.

$$
\% \text { of organic carbon }=\{0.1 \times(B-S) \times N \times 0.003 \times(100 / W)\} \times C
$$


Where; $\mathrm{B}=$ blank reading, $\mathrm{S}=$ sample reading, $\mathrm{N}=$ represents the normality of $\mathrm{K}_{2} \mathrm{Cr}_{2} \mathrm{O}_{7}$ solution, $\mathrm{W}=$ weight of soil taken and $\mathrm{C}=$ correction factor

\subsection{Determination of total nitrogen, phosphorus and potassium}

Total Nitrogen was determined by the Kjeldhal method [13] with minor modifications. One gram of air dried sample was added to $5 \mathrm{gm}$ of digestion mixture $\left(5: 1\right.$ of $\mathrm{K}_{2} \mathrm{SO}_{4}$ : $\mathrm{CuSO}_{4}$ ) followed by $20 \mathrm{ml}$ of concentrated $\mathrm{H}_{2} \mathrm{SO}_{4}$. The mixture was heated at $420^{\circ} \mathrm{C}$ in an automated Kjeldahl digestion tube until it turned to blue colour. The digested solution was cooled to room temperature and transferred to $100 \mathrm{ml}$ volumetric flask. The volume was adjusted with distilled water. $20 \mathrm{ml}$ of the digested sample was taken in automated Kjeldhal distillation tube, $20 \mathrm{ml} 40 \% \mathrm{NaOH}$ and $10 \mathrm{ml}$ distilled water was added to it. The reaction mixture was distilled and the ammonia released was absorbed in $10 \mathrm{ml} 2 \%$ boric acid solution (containing mixed indicator of Bromocresol Green and Methyl Red) in a 100 ml conical flask. Distillation was conducted for 10 min until the colour change of boric acid from purple to green was prominent. The trapped ammonia in boric acid was titrated against $0.05 \mathrm{~N} \mathrm{H}_{2} \mathrm{SO}_{4}$. One blank sample was run in a similar manner. Calculation was conducted as

$$
\% \text { of total nitrogen }=0.014 \times S \times V \times d f \times 100
$$

Where, $\mathrm{S}=$ Strength of $\mathrm{H}_{2} \mathrm{SO}_{4}, \mathrm{~V}=$ Volume of $\mathrm{H}_{2} \mathrm{SO}_{4}$ required and $\mathrm{df}=$ Dilution factor

Preparation of sample for estimation of phosphorus as phosphate and potassium as potash requires di-acid digestion. One gram sample was subjected to di-acid digestion for available phosphate and the final volume was adjusted to 100 $\mathrm{ml}[14]$.

Available phosphorus in the digested sample solution in form of phosphate was conducted by the protocol developed by Bray and Kurtz (1945) [15]. $10 \mathrm{ml}$ of digested sample was taken in a volumetric flask. The phosphate content in the solution was measured in a precallibrated spectrophotometer $(660 \mathrm{~nm})$ by adding ammonium molybdate $(10 \mathrm{ml})$ and thereafter reducing the molybdenum-phosphate complex with stannous chloride (2 ml) and water to make $50 \mathrm{ml}$ [13]. Quantification of phosphate (ppm) was calculated by following equation.

$$
\text { Quantification of phosphate }=\text { Concentration in }(p p m) X \text { dilution factor }
$$

Determination of available potassium form of Potash was conducted by the protocol developed by Chapman and Pratt, $1961[16] .20 \mathrm{ml}$ of the extracted sample was taken in a beaker. 2 drops of butyl alcohol were added to the filtrate and potash was estimated with pre standardized flame photometer. The potash contented of the filtrate was determined from equation.

\section{Quantification of potash $=$ Flamephotometer reading $(p p m) X$ dilution factor}

\section{Results and discussion}

\subsection{Moisture content}

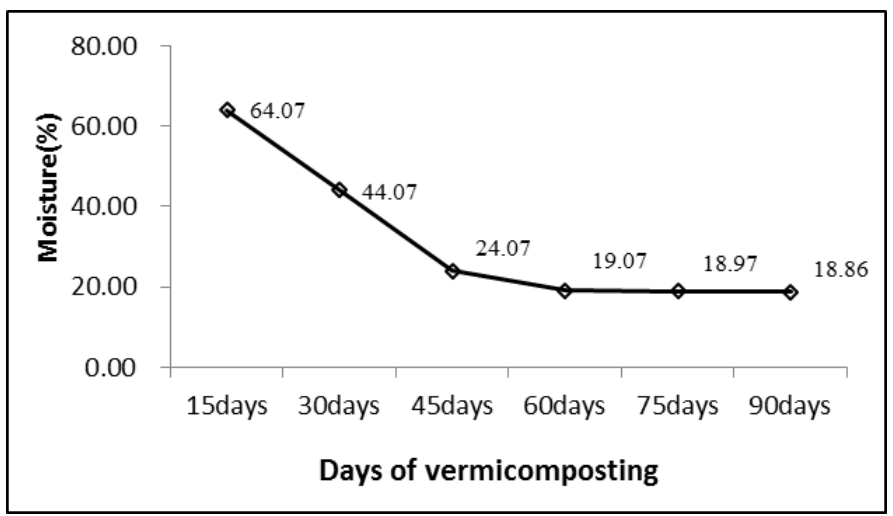

Figure 1 Changes of moisture content during vermicomposting 
Moisture content of vermicompost is very crucial for survival and balanced metabolism of earthworms and microbial population. The moisture content declined gradually from the initial days of experiment to its termination (Figure1). After $60^{\text {th }}$ day of composting the moisture content reached a plateau and thereafter the moisture content declined quite insignificantly. The maximum moisture content was recorded on $15^{\text {th }}$ day $(64.07 \%)$ and the minimum moisture content was recorded on $90^{\text {th }}$ day (18.86).

\section{2. pH of vermicompost}

The alkalinity or acidity of organic fertilizers is an important determinant for its quality. pH changes can decline enzymatic activities and microbial growth, thereby inhibiting release of nutrients to soil. pH of the samples (Figure 2) varied from alkaline (8.01) to acidic level (6.55). Rise in $\mathrm{pH}$ level was observed on $30^{\text {th }}$ day but thereafter declined gradually till $75^{\text {th }}$ day. There was a slight rise in $\mathrm{pH}$ level after $75^{\text {th }}$ day.

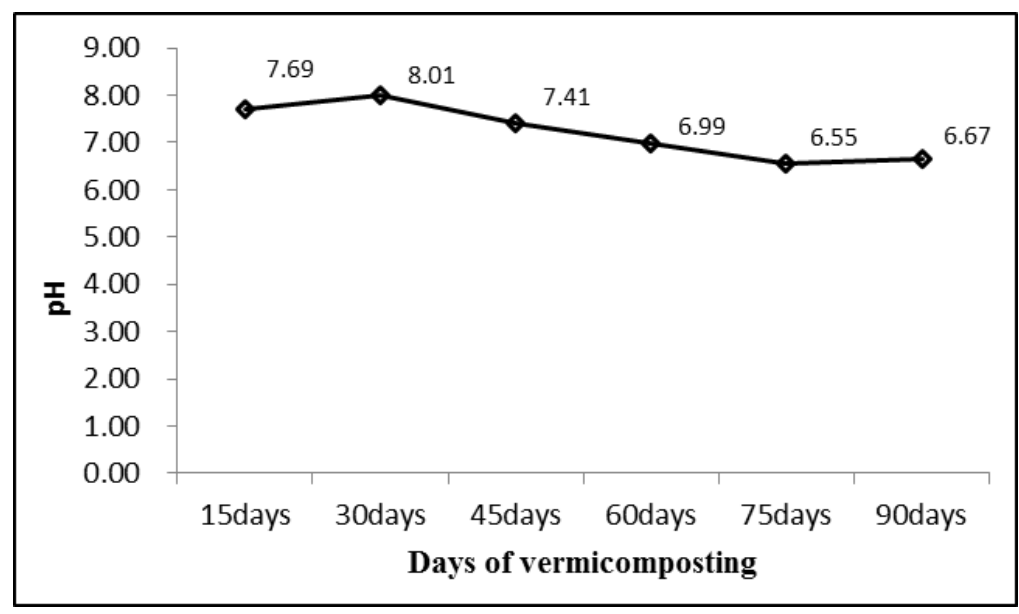

Figure 2 Changes of $\mathrm{pH}$ during vermicomposting

\subsection{Organic carbon content of vemicompost}

The role of organic matter, in relation to soil fertility and physical conditions, are widely recognized. Organic matter takes part in stabilization of soil structure and in nutrient cycling [17-19]. The organic carbon content of the vermicast changed with time (Figure 3). The maximum percentage organic carbon in the vermicast was recorded to $32.87 \%$. The percentage of organic carbon varied between $21.77 \%$ to $32.87 \%$.

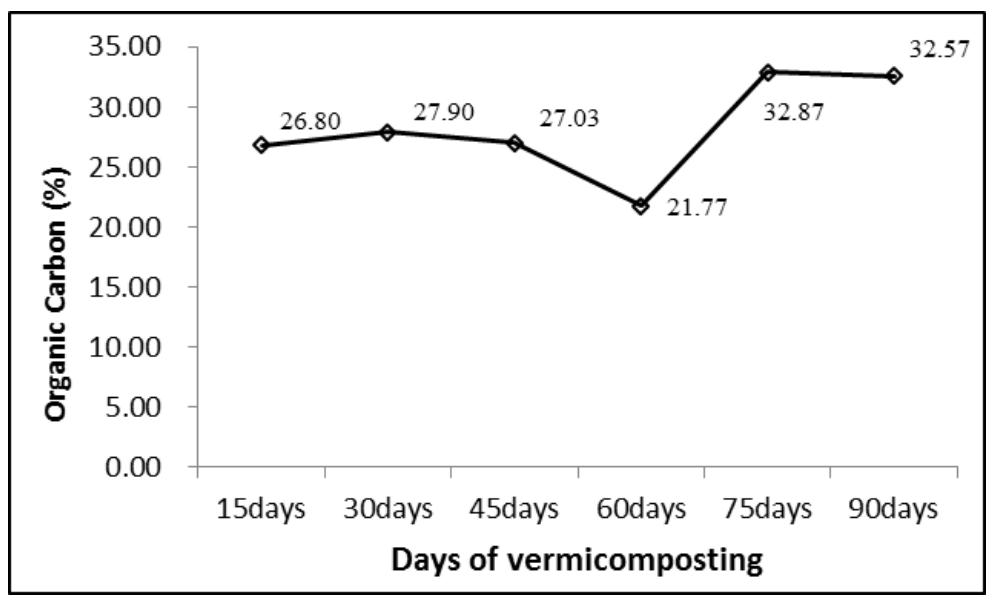

Figure 3 Changes of organic carbon content during vermicomposting

\subsection{NPK content of vemicompost}

Nitrogen, phosphorus and potassium are the three most important mineral nutrients on which the metabolisms of plants depend. Their deficiency for plants is the most limiting factor for growth and development. Total nitrogen, available phosphorus in form of phosphate and available potassium in form of potash increased gradually during the 
process of vermicomposting with minor deviations (Table 1). The percentage of nitrogen varied from 1.53 to $1.78 \%$. The maximum content of total nitrogen was detected in the sample tested on $90^{\text {th }}$ day. The percentage of available phosphorus ranged between 0.15 to $0.44 \%$. The maximum content of phosphorus in form of phosphate was detected on $60^{\text {th }}$ day then the content of potash declined with time. The percentage of available potassium in from of potash ranged between 0.65 to $1.05 \%$. The content of available potash increases gradually with time to show it's highest on $75^{\text {th }}$ day and then declined. Weed biomass collected from tea plantations supplemented with cowdung can be used as a good substrate to produce eco-friendly substitute of chemical fertilizers. By this technique nutrient rich vermicompost can be collected after $60^{\text {th }}$ day of culture. The C:N ratio produced vermicompost is around 15:1.

Table 1 NPK content of vermicompost during its preparation

\begin{tabular}{lcccccc}
\hline & \multicolumn{7}{c}{ Days } \\
Nutrients & $\mathbf{1 5}$ & $\mathbf{3 0}$ & $\mathbf{4 5}$ & $\mathbf{6 0}$ & $\mathbf{7 5}$ & $\mathbf{9 0}$ \\
\hline Nitrogen & 1.53 & 1.56 & 1.58 & 1.59 & 1.63 & 1.78 \\
Phosphorus & 0.15 & 0.17 & 0.11 & 0.44 & 0.25 & 0.19 \\
Potassium & 0.73 & 0.84 & 0.65 & 0.65 & 1.05 & 0.89 \\
\hline
\end{tabular}

\section{Conclusion}

Population is increasing day by day. Though the crop yield is being increased many times by application of chemical fertilizers, but simultaneously there is problem on environment pollution which leads to human and animal health hazards. Huge quantities of weeds grow in tea plantations, so conversion of their biomass to vermicompost to some extend may reduce the excessive use of chemical fertilizers.

\section{Compliance with ethical standards}

\section{Acknowledgments}

The authors will like to thank the Head, Department of Tea Science, University of North Bengal for providing infrastructural support.

\section{Disclosure of conflict of interest}

The authors declare that there is no conflict of interest.

\section{References}

[1] Edwards CA and Baxter JE. (1992). The use of earth worms in environmental management. Soil Biology and Biochemistry, 24(12), 1683-1689.

[2] Long C. (2000). Wonders of Wigglers. Organic gardening, 47(3), 12.

[3] Lotzof M. (1999). Adopting sustainable technology to manage organic waste. Vericulture- a case study. "Australia China Environment Workshop, Beijing.

[4] Saha N, Das AC and Mukherjee D. (1995). Effect of decomposition of organic matter on the activities of microorganisms and availability of nitrogen, phosphorus and sulpher in soil. Journal of Indian Society of Soil Science, 43, 210-215.

[5] Epstein E. (1997). The science of composting.Technomic Publication Co. Inc., U. K.

[6] Satchel JE and Martin K. (1984). Phosphatase activity in earthworm faeces. Soil Biology Biochemistry, 16, 191194.

[7] Tiwari SC, Tiwari BK, and Mishra RR. (1989). Microbial community, enzyme activity and $\mathrm{CO}_{2}$ evolution in pineapple orchard. Soil Tropical Ecology, 30, 265-273. 
[8] Yevdokimova TI, Borzova TF, Bykoskaya TK, Skvortsova IN, UI Janova T, Yu and Filyayevskikv U. (1991). Biological activity of irrigated and unirrigated chernozymes of southern klundastreppe. Soviet Soil Science. 23, 13-21.

[9] Kakazawa M, Mura A and Takhara Y. (1990). A two-step composting process for woody resources. Journal of Fermentation and Bioengineering. 70, 173-176.

[10] Kakazawa M, Mura A and Takhara Y. (1992). Application of two step composting process to rice straw compost. Soil Science and Plant Nutrient, 38, 105-109.

[11] Michel Jr, FC, Reddy CA, and Forney LJ. (1993). Yard waste composting: studies using different mixes of leaves and grass in a laboratory scale system. Compost Science \& Utilization, 1(3), 85-96.

[12] Walkley A and Black CA. (1974). Critical examination of rapid method of determining organic carbon in soil. Soil Science. 63, 251-164.

[13] Jackson ML. (1973). Soil Chemical Analysis. Prentice Hall (India), Pvt. Ltd.

[14] Baruah TC and Barthakur HP. (1997). A Textbook of Soil Chemical Analysis. Vikash, New Delhi.

[15] Bray RH and Kurtz LT. (1945). Determination of total, organic, and available forms of phosphorus in soils. Soil science, 59(1), 39-46.

[16] Chapman HD and Pratt PF. (1961). Plant analysis. Methods of analysis for soils, plants and waters, 56-64.

[17] Dick RP. (1992). A review: long-term effects of agricultural systems on soil biochemical and microbial parameters. In Biotic Diversity in Agroecosystems, 25-36.

[18] Quilchano C and Marañón T. (2002). Dehydrogenase activity in Mediterranean forest soils. Biology and Fertility of Soils, 35(2), 102-107.

[19] Singh, S, Pandey A, Kumar B and Palni LMS. (2010). Enhancement in growth and quality parameters of tea [Camellia sinensis (L.) 0. Kuntze] through inoculation with arbuscular mycorrhizal fungi in an acid soil. Biology and fertility of soils, 46(5), 427-433.

\section{How to cite this article}

Mukherjee M, Sarkar S, Saha S and Bhattacharya M. (2018). Utilization of tea plantation weeds to produce vermicompost and estimation of physiochemical changes during its production. GSC Biological and Pharmaceutical Sciences, 5(3), 136141. 